\title{
Metabasite bodies as chronological and structural markers in the gneisses east of Sãtut, Umanak district, central West Greenland
}

\section{Lasse Schiøtte}

The occurrence of pod-like and more irregularly shaped discordant metabasite bodies in the Umanak district was mentioned by Pulvertaft (1973) and their potential as chronological and structural markers was reiterated by Pulvertaft (1979). However, in many other basement areas where irregular metabasite bodies occur, it has been found that irregularities of form and structure are better interpreted as consequences of synkinematic intrusion rather than post-intrusion deformation, so the use of metabasic intrusions as chronological markers is not so straightforward as might appear at first sight (see for example papers and references in Korstgård, 1979).

Large, more or less discordant bodies, of basic-ultrabasic rock in the gneisses on the islands and mainland east of Sãtut have been found in many cases to possess a primary asymmetric distribution of rock types which enables one to distinguish bodies that are inverted in relation to one another. This in turn can be used to establish that at least one phase of recumbent isoclinal folding has taken place since the intrusion of the bodies.

The bodies have either pod-like or tabular shape, and are up to hundreds of metres long by nearly a hundred metres thick. Although their shape orientation is usually more or less parallel to the trend in the surrounding gneisses, their long edges often show discordance at a narrow angle to the foliation in the contact gneiss. At blunt ends either the gneiss foliation bends round to wrap the metabasite, or pegmatite is present.

The primary assymmetry is marked by the distribution of a gabbro-noritic rock type and an ultrabasic type. The boundary between these is usually a zone of rapid transition less than $10 \mathrm{~cm}$ wide which is subparallel to the long edges of the body. Sometimes the ultrabasic rock wedges out along a long edge, but more often the gabbro-norite-ultrabasic boundary is cut off at the blunt end of the body.

The gabbro-norite has largely retained its igneous texture and mineralogy. The main minerals are orthopyroxene, clinopyroxene, and labradoritic plagioclase which may be clouded. The mafic minerals amount to about 60 per cent of the rock. Minor biotite (less than 1 per cent) may be present and apparently has not grown at the expense of the other minerals.

The ultrabasic rock type is often highly serpentinised. It seems however to have been an olivine websterite or olivine orthopyroxenite dominated by large crystals of orthopyroxene. Olivine seems to have formed about 30 per cent of the rock and occurs mainly enclosed in orthopyroxene. There is about 5-10 per cent opaque material in the rock. The ultrabasic rock may be a cumulate, although it is difficult to demonstrate unambiguous cumulate textures due to the effects of alteration.

The metabasite bodies show varying degrees of alteration along their margins. Where discordance along the long edges has been erased, the gabbro-norite has been altered to amphibolite, while the ultrabasic rock has been altered to biotite hornblendite. Where there has not been shearing, and primary contact features have been preserved, there is often a clear difference between the ultrabasite-gneiss contact on the one hand and the gabbro-no- 


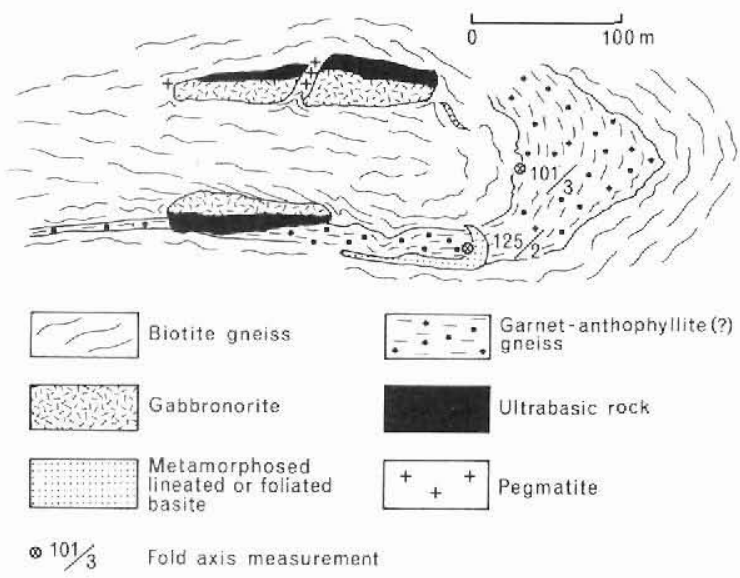

Fig. 12. Profile of isoclinal fold affecting metabasite bodies. South-west slope of Qíngup qáqâ, east of Sātut.

Q $101 / 3 \quad$ Fold axis measurement

rite-gneiss contact on the other: the former is sharp while the latter is diffuse gabbro-norite grading through structureless gneiss into normal gneiss in about $10 \mathrm{~cm}$. These contrasting contacts add to the asymmetry of the bodies.

At two localities in the area a relative inversion between metabasite bodies situated at two levels can be seen to be related to folds. Fig. 12 is a profile of one of these localities, drawn roughly at right angles to the mean of the fold axes in the gneiss and the folded metabasite, respectively. The difference in the direction of these axes is attributed to the discordance of the metabasite.

The relations shown in fig. 12 are regarded as clear evidence that the recumbent isocline in the gneiss developed after the intrusion of the metabasite bodies and is the cause of the relative inversion of the bodies on either flank of the fold. If the ultrabasic rock is a cumulate, the fold is a recumbent syncline.

Although tight isoclinal recumbent folds are quite common in the area east of Sătut, none have been seen cross-cut by metabasite intrusions. For this reason the author doubts if there has been any recumbent folding in this area between the event leading to the interleaving of gneiss and supracrustal amphibolite (see the previous article in this report) and the intrusion of the gabbro-norite-ultrabasic bodies. In contrast Grocott (see the previous article) believes that the large metabasite bodies around Ũmatsiaq postdate isoclinal folding in this area. The Ümánatsiaq bodies do not resemble the gabbro-norite-ultrabasic bodies, being amphibolites with igneous texture and only 30-40 per cent mafic minerals which may include garnet. According to Grocott (personal communication) these Ũmánatsiaq bodies resemble rock types found in the Kangâmiut dykes of the Søndre Strømfjord area. Thus the late Archaean - early Proterozoic intrusive events in the Umanak district may parallel the sequence of basic intrusions in the Nagssugtoqidian belt of East Greenland (Bridgwater \& Myers, 1979).

\section{References}

Bridgwater, D. \& Myers, J. S. 1979: Outline of the Nagssugtoqidian mobile belt of East Greenland. Rapp. Groniands geol. Unders. 89, 9-18. 
Grocott, J. 1981: Structural evolution of the Ikerasak area, Umanak district, central West Greenland. Rapp. Grønlands geol. Unders. 105 (this volume).

Korstgård, J. A. (edit.) 1979: Nagssugtoqidian geology. Rapp. Grønlands geol. Unders. 89, 146 pp.

Pulvertaft, T. C. R. 1973: Recumbent folding and flat-lying structure in the Precambrian of northern West Greenland. Phil. Trans. R. Soc. Lond. A 273, 535-545.

Pulvertaft, T. C. R. 1.979: Mapping in the Umanak district, central West Greenland. Rapp. Grønlands geol. Unders. 95, 27-30.

Institut for almen Geologi, $\emptyset$ ster Voldgade 10 DK-1350 Copenhagen $K$

\section{Coal in West Greenland}

\section{S. Chandra Shekhar, N. Frandsen and E. Thomsen}

The 1980 summer field season for the 'Coal Project' (Frandsen \& Shekhar, 1980) began about the first week of April. Longyear Canada Inc. carried out the drilling on Nûgssuaq, and Greenex A/S were the management consultants. Eighteen profiles were measured in the Atâ-Pautût region and another profile was measured in the Kingigtoq area. Eight slit samples of selected coal seams were taken for analysis.

\section{Fossiliferous sequence at Atâta kûa}

Several sections were measured on the north side of the valley Atâta kûa (fig. 13). These were all sections of the ordinary coal-bearing sequence except for the westernmost section (location 11, fig. 13). The sediments of this section have a west-north-westerly dip of $10^{\circ}$ in contrast to the almost horizontal coal-bearing sediments of the area, and the total measured thickness of the sediments, which are black to brownish shale, is $74 \mathrm{~m}$. Intercalated in the shale are four zones between $0.4 \mathrm{~m}$ and $1.9 \mathrm{~m}$ thick. The zones are either continuous bands or long, flat lenses of very coarse to pebbly sandstone interbedded with dark grey shale, individual beds having a thickness between a few millimetres and a few centimetres. The sandstone beds have a very hard, dark brown matrix and some contain abundant molluscs while some of the shale beds contain well preserved leaf impressions.

The lower half of the section contains scattered lenticular concretions. The concretions are dark brown and very hard, $20-30 \mathrm{~cm}$ thick and up to $1 \mathrm{~m}$ long.

The shale is underlain by a badly exposed, very coarse conglomerate with boulders up to 1 $\mathrm{m}$. The boulders are sedimentary rocks in a matrix of coarse sandstone with rounded quartzite pebbles.

More work on the fossils of this section is required before an interpretation of age and depositional environment is possible, but tentatively it is suggested that the sediments can be correlated with the marine rocks of the Danian Kangilia or Agatdal Formations (Rosenkrantz, 1970). 